\title{
Upaya Meningkatkan Imunitas Tubuh Pada Masa Pandemi Covid 19 Di Majelis Taklim Masjid Ar Ridho
}

\author{
DOI: https://doi.org/10.32509/abdimoestopo.v5i1.1761
}

\author{
Afina Muharani Syaftriani ${ }^{*}$, Mulidan², Khairuni Ramadhani ${ }^{3}$ \\ Program Studi Diploma Tiga Keperawatan Institut Kesehatan Helvetia \\ Jalan Kapten Sumarsono No. 107, Deli Serdang, Sumatra Utara 20124 \\ *Email Korespondensi: afinamuharanisyaftriani@helvetia.ac.id
}

\begin{abstract}
COVID 19 has now become a pandemic and a world health problem, especially in Indonesia. The number of positive cases of COVID 19 in Indonesia is the highest in the Asian region. Over the next few months the Indonesian nation will face big problems caused by COVID 19, if not handled properly. Facing a situation like this, it is necessary to control and prevent COVID 19. Prevention efforts can be done by increasing community resilience, through individual body health or by increasing and maintaining the body's immunity (immunity). The purpose of implementing this community service is to provide education to the women of the Ar Ridho Mosque taklim regarding efforts to increase body immunity during the COVID 19 pandemic. The method used in the implementation of this community service is to provide counseling through lectures and provide leaflets containing counseling materials at Taklim Council of Ar Ridho Mosque Jalan Abdul Hakim Gg. Ar Ridho Mosque, Tanjung Sari, Medan Selayang, Medan City, North Sumatra, 20132. The target group for the activity was the women of the Ar Ridho Mosque Taklim Council. The results of this community service have a positive impact on the parties involved, especially for the women of the taklim assembly of the Ar Ridho Mosque. Based on the results obtained, it can be concluded that there was an increase in the knowledge and skills of the counseling participants, namely the women of the Ar-Ridho Mosque taklim regarding the importance of increasing body immunity during the Covid-19 pandemic as an effort to prevent Covid-19 transmission.
\end{abstract}

Keywords: Covid 19, Immunity, Pandemic

\begin{abstract}
Abstrak - COVID 19 saat ini telah menjadi pandemi dan menjadi masalah kesehatan dunia khususnya di Indonesia. Jumlah kasus positif COVID 19 di Indonesia merupakan yang tertinggi di wilayah Asia. Selama beberapa bulan ke depan bangsa Indonesia akan menghadapi masalah besar disebabkan COVID 19, apabila tidak ditangani dengan tepat. Menghadapi situasi seperti ini, maka diperlukan upaya pengendalian dan pencegahan COVID 19. Upaya pencegahan dapat dilakukan dengan meningkatkan ketahanan masyarakat, melalui kesehatan tubuh perorangan atau dengan meningkatkan dan menjaga daya tahan (imunitas) tubuh. Tujuan pelaksanaan pengabdian masyarakat ini adalah untuk memberikan edukasi pada ibu-ibu majelis taklim Masjid Ar Ridho terkait upaya peningkatan imunitas tubuh di masa pandemic COVID 19. Metode yang digunakan dalam pelaksanaan pengabdian masyarakat ini adalah dengan memberikan penyuluhan melalui ceramah dan memberikan leaflet berisi materi penyuluhan di Majelis Taklim Masjid Ar Ridho Jalan Abdul Hakim Gg Masjid Ar Ridho, Tanjung Sari, Medan Selayang, Kota Medan, Sumatera Utara, 20132. Sasaran pelaksanaan kegiatan adalah ibu-ibu majelis taklim Masjid Ar Ridho. Hasil pengabdian masyarakat ini memberikan dampak positif bagi pihak-pihak yang terlibat, khususnya bagi ibu-ibu majelis taklim Masjid Ar Ridho. Berdasarkan hasil yang diperoleh dapat disimpulkan bahwa terjadi peningkatan pengetahuan dan keterampilan peserta penyuluhan yaitu ibu-ibu majelis taklim Masjid Ar-Ridho mengenai pentingnya meningkatkan imunitas tubuh di masa pandemi Covid-19 sebagai upaya pencegahan penularan Covid-19.
\end{abstract}

Kata Kunci : Covid 19, Imunitas Tubuh, Pandemi 


\section{PENDAHULUAN}

COVID 19 saat ini telah menjadi pandemi dan menjadi masalah kesehatan dunia. COVID 19 merupakan penyakit yang disebabkan virus Sars-Cov-2 dan ditularkan antara manusia. Kasus COVID 19, diawali dengan informasi dari Badan Kesehatan Dunia/ World Health Organization (WHO) pada tanggal 31 Desember 2019 yang menyebutkan adanya kasus kluster pneumonia dengan etiologi yang tidak jelas di Kota Wuhan, Provinsi Hubei, China. Kasus ini terus berkembang hingga akhirnya diketahui bahwa penyebab kluster pneumonia ini adalah novel coronavirus. Kasus ini terus berkembang hingga adanya laporan kematian dan terjadi importasi di luar China. Pada tanggal 30 Januari 2020, WHO menetapkan COVID 19 sebagai Public Health Emergency of International Concern (PHEIC)/ Kedaruratan Kesehatan Masyarakat yang Meresahkan Dunia (KKMMD). Pada tanggal 12 Februari 2020, WHO resmi menetapkan penyakit novel coronavirus pada manusia ini dengan sebutan Coronavirus Disease (COVID 19) (WHO, 2020).

Di Indonesia sendiri, kasus pertama COVID 19 dilaporkan pada 2 Maret 2020. Wilayah penyebaran COVID 19 di Indonesia tersebar luas hampir di semua provinsi. Jumlah pasien yang terinfeksi COVID 19 juga terus bertambah. Virus COVID 19 sudah menjadi permasalahan bagi seluruh penduduk Indonesia. Virus ini sudah menyebabkan lebih dari satu juta penduduk Indonesia terkonfirmasi positif COVID 19, 32.358 pasien meninggal dunia dan 992.492 terkonfirmasi telah pulih dari virus COVID 19. Jumlah kasus positif COVID 19 di Indonesia merupakan yang tertinggi di wilayah Asia. Selama beberapa bulan ke depan bangsa Indonesia akan menghadapi masalah besar disebabkan COVID 19, apabila tidak ditangani dengan tepat (2).

Menghadapi situasi seperti ini, maka diperlukan upaya pengendalian dan pencegahan COVID 19. Kementerian Kesehatan Republik Indonesia telah menerbitkan panduan kepada masyarakat dalam menghadapi COVID 19 (Kemenkes Ri, 2020). Upaya pencegahan dapat dilakukan dengan meningkatkan ketahanan masyarakat, melalui kesehatan tubuh perorangan atau dengan meningkatkan dan menjaga daya tahan (imunitas) tubuh (Liu et al, 2020).

Imunitas atau daya tahan tubuh merupakan suatu reaksi dalam tubuh terhadap bahan asing yang masuk ke dalam tubuh secara molekuler atau seluler. Daya tahan tubuh merupakan salah satu faktor yang mempengaruhi kemampuan tubuh untuk mempertahankan kondisi tubuh dalam melawan penyakit, terutama penyakit yang disebabkan oleh virus. Daya tahan tubuh dapat dijaga dan ditingkatkan, utamanya melalui: (1) kebiasaan hidup sehat dengan menjaga kebersihan dan rutin berolah raga, (2) cukup waktu istirahat, (3) asupan nutrisi yang baik (seperti lebih banyak mengkonsumsi sayur dan buah, (4) menjalankan protokol kesehatan seperti menjaga jarak, cuci tangan secara teratur, memakai masker dan menjaga etika ketika batuk dan bersin, dan (5) menghindari stress. Upaya untuk menjalankan protokol kesehatan ini juga sudah dilakukan kepada masyarakat di Kampung Kroyo, Karangmalang Sragen (Mutmainah \& Jamilatun, 2021) dengan cara menerapkan PHBS (Perilaku Hidup Bersih dan Sehat). Selain itu, upaya yang dapat dilakukan masyarakat untuk mencegah penularan virus corona adalah dengan meningkatkan daya tahan tubuh dengan mengkonsumsi vitamin, suplemen dan ramuan tanaman herbal yang berkhasiat sebagai imunomodulator (peningkat daya tahan tubuh) (Liu et al, 2020).

Sistem imunitas atau imunitas tubuh memiliki peran penting dalam menjaga kesehatan. Imunitas tubuh harus dijaga dengan baik agar tidak mudah terserang penyakit. Imunitas tubuh yang baik dapat menjaga kita sejak pertama kali kuman atau virus masuk ke dalam tubuh. Memiliki daya tahan (imunitas) tubuh yang kuat sangat penting untuk mencegah kita jatuh sakit, terutama di masa mewabahnya virus COVID 19 seperti sekarang. Oleh karena itu, proposal ini bertujuan untuk memberikan pendidikan kesehatan atau penyuluhan tentang Upaya Meningkatkan Imunitas Tubuh di Masa Pandemi Covid 19 (Liu et al, 2020). 


\section{METODE PELAKSANAAN}

Metode pelaksanaan pada kegiatan Pengabdian Kepada Masyarakat (PKM) dimulai dari tahap persiapan hingga laporan kegiatan PKM dilakukan selama lima bulan (Mei 2021September 2021). Metode pelaksanaan pengabdian ini dilakukan tiga tahap yaitu tahap persiapan, pelaksanaan dan penutup. Kegiatan program PKM ini diawali dengan melakukan analisis kebutuhan mitra PKM melalui survey atau wawancara kepada Ketua BKM Masjid Ar Ridho guna mengetahui kebutuhan materi penyuluhan yang diperlukan oleh peserta penyuluhan, kemudian dilanjutkan dengan berkoordinasi terkait persiapan kegiatan PKM bersama dengan Ketua BKM Masjid Ar Ridho. Selanjutnya dilakukan pembutaan proposal kegiatan PKM sebagai salah satu syarat administrasi wajib di Institut Kesehatan Helvetia. Tahapan berikutnya adalah pembuatan materi penyuluhan (pendidikan kesehatan) sesuai dengan materi yang akan disampaikan kepada peserta penyuluhan yaitu mengenai "Upaya Meningkatkan Imunitas Tubuh Di Masa Pandemic Covid 19". Setelah membuat materi penyuluhan (pendidikan kesehatan), tahapan selanjutnya adalah penentuan jadwal penyuluhan (pendidikan kesehatan). Untuk penentuan jadwal pelaksanaan penyuluhan (pendidikan kesehatan) pihak dosen yang melaksanakan PKM berkoordinasi dengan Ketua BKM Masjid Ar Ridho dan Ketua Majelis Taklim Masjid Ar Ridho. Setelah koordinasi dilkaukan, ditentukanlah kegiatan PKM dilakukan pada hari Selasa, 06 Juli 2021 di Majelis Taklim Masjid Ar Ridho Jalan Abdul Hakim Gg Masjid Ar Ridho, Tanjung Sari, Medan Selayang, Kota Medan, Sumatera Utara.

Tahapan berikutnya adalah pelaksanaan kegiatan penyuluhan (pendidikan kesehatan). Kegiatan Pengabdian Kepada Masyarakat (PKM) yang dilaksanakan di Masjid Ar- Ridho Jalan Abdul Hakim Gg Masjid Ar Ridho, Kelurahan Tanjung Sari, Kecamatan Medan Selayang, Kota Medan, Sumatera Utara ini dilaksanakan selama satu hari yakni pada hari Selasa tanggal 06 Juli 2021. Kegiatan PKM ini berlangsung dari pukul 16.00-17.30 WIB. Kegiatan PKM ini dilaksanakan setelah ibu-ibu majelis taklim Masjid Ar Ridho melaksanakan pengajian dan mendengarkan ceramah. Kegiatan PKM ini berlangsung secara tatap muka dengan metode ceramah dan diskusi terkait materi tentang peningkatan imunitas tubuh di masa pandemi Covid 19. Penyuluhan pendidikan kesehatan dimulai dengan menggali dan mengkaji pengetahuan ibu-ibu majelis taklim Masjid Ar Ridho tentang peningkatan imunitas tubuh di masa pandemi Covid 19 (Gambar 1). Dosen pemateri menanyakan kepada ibu-ibu majelis taklim Masjid Ar Ridho apa yang mereka ketahui tentang imunitas tubuh di masa pandemi. Beberapa peserta penyuluhan pendidikan kesehatan mengatakan bahwa imunitas tubuh itu hanya sebatas merasa sehat dan terhindar dari penyakit, peserta penyuluhan pendidikan kesehatan belum memahami bagaimana cara meningkatkan imunitas tubuh tersebut di masa pandemi covid 19 ini. Setelah itu dosen pemateri yang merupakan Dosen Fakultas Farmasi dan Kesehatan, Prodi D3 Keperawatan, Institut Kesehatan Helvetia menyampaikan materi penyuluhan pendidikan kesehatan dengan topik, "Upaya Meningkatkan Imunitas Tubuh Di Masa Pandemi Covid 19" (Gambar 2). Kegiatan ini diakhiri dengan diskusi dan tanya jawab dengan ibu-ibu majelis taklim Masjid Ar Ridho. Berbagai pertanyaan diajukan secara antusias oleh para peserta dalam PKM ini. Selama proses tanya jawab, ibu-ibu majelis taklim Masjid Ar Ridho terlihat antusias karena menjawab permasalahan yang selama ini sedang dihadapi.

\section{HASIL PENEMUAN DAN DISKUSI}

Kegiatan Pengabdian Kepada Masyarakat (PKM) yang dilaksanakan di Masjid ArRidho Jalan Abdul Hakim Gg Masjid Ar Ridho, Kelurahan Tanjung Sari, Kecamatan Medan Selayang, Kota Medan, Sumatera Utara ini dilaksanakan selama satu hari yakni pada hari Selasa tanggal 06 Juli 2021. Kegiatan PKM ini berlangsung dari pukul 16.00-17.30 WIB. 
Kegiatan PKM ini dilaksanakan setelah ibu-ibu majelis taklim Masjid Ar Ridho melaksanakan pengajian dan mendengarkan ceramah. Peserta kegiatan PKM ini berjumlah 23 orang ibu-ibu majelis taklim Masjid Ar Ridho.

Kegiatan PKM ini berlangsung secara tatap muka dengan metode ceramah dan diskusi terkait materi tentang peningkatan imunitas tubuh di masa pandemi Covid 19. Penyuluhan pendidikan kesehatan dimulai dengan mengkaji pengetahuan ibu-ibu majelis taklim Masjid $\mathrm{Ar}$ Ridho tentang peningkatan imunitas tubuh di masa pandemi Covid 19. Setelah itu dosen pemateri menyampaikan materi penyuluhan kesehatan dengan topik, "Upaya Meningkatkan Imunitas Tubuh Di Masa Pandemi Covid 19”. Kegiatan ini diakhiri dengan diskusi dan tanya jawab dengan ibu-ibu majelis taklim Masjid Ar Ridho. Berbagai pertanyaan diajukan secara antusias oleh para peserta dalam PKM ini. Selama proses tanya jawab, ibu-ibu majelis taklim Masjid Ar Ridho terlihat antusias karena menjawab permasalahan yang selama ini sedang dihadapi.

Program PKM yang dilaksanakan di majelis taklim Masjid Ar Ridho ini memberikan hasil yang positif dan signifikan yang dapat dirasakan tidak hanya oleh ibu-ibu majelis taklim Masjid Ar Ridho tetapi juga dosen dan mahasiswa yang terlibat. Bagi ibu-ibu majelis taklim Masjid Ar Ridho, program ini memberikan kesempatan ibu-ibu majelis taklim Masjid Ar Ridho untuk dapat mengetahui upaya peningkatan imunitas tubuh di masa pandemi Covid 19. Ibu-ibu majelis taklim Masjid Ar Ridho sangat antusias mengikuti kegiatan PKM dengan suasana yang sangat menyenangkan melalui media yang digunakan. Ibu-ibu majelis taklim Masjid Ar Ridho dapat berinteraksi secara aktif, menerangkan kembali materi penyuluhan yang telah diberikan dosen pemateri dengan lugas dan tepat. Hal ini juga dapat dilihat dari pengetahuan ibu-ibu majelis taklim Masjid Ar Ridho sebelum dan sesudah pemberian penyuluhan tentang upaya peningkatan imunitas tubuh di masa pandemi Covid 19.

Bagi mahasiswa Institut Kesehatan Helvetia Fakultas Farmasi dan Kesehatan khususnya pada prodi D3 Keperawatan, program ini telah memberikan pengalaman baru mahasiswa dalam melakukan pengabdian kepada masyarakat pada tingkat pemula.

Pengabdian kepada masyarakat yang dilakukan di majelis taklim Masjid Ar Ridho mendapatkan hasil bahwa tingkat pengetahuan ibu-ibu majelis taklim Masjid Ar Ridho ratarata masih kurang tentang penyakit Covid 19 dan imunitas tubuh. Hal ini dibuktikan ketika dosen pemateri memberikan pertanyaan terkait apa itu Covid 19 dan imunitas tubuh, ibu-ibu majelis taklim Masjid Ar Ridjho mayoritas mengatakan tidak mengetahui apa itu Covid 19 dan imunitas tubuh tersebut. Salah satu ibu-ibu majelis taklim Masjid Ar Ridho juga mengatakan belum ada penyuluhan yang membawakan tentang materi Covid 19 dan imunitas tubuh tersebut.

Corona virus atau Virus corona adalah hal yang familiar di dunia kesehatan hewan. Virus ini termasuk salah satu kelompok virus ribonukleat acid (RNA) yang menjangkit mamalia dan burung. Virus ini dapat menginfeksi manusia sehingga bagi yang terinfeksi virus akan terjangkit penyakit mulai dari penyakit ringan seperti batuk kering, deman dan lain-lain. Jika bertambah parah, infeksi covid-19 dapat berkembang menjadi gagal napas yang terkait dengan kerusakan alveolar difus dan sindrom gangguan pernapasan akut (Moderbacher et al, 2020). Tubuh manusia memiliki sistem kekebalan untuk melawan benda asing (patogen) yang akan ke dalam tubuh, atau biasa disebut imunitas tubuh. Imunitas tubuh adalah pertahanan tubuh manusia dalam menghalau patogen seperti bakteri, virus, dan patogen lainnya. Apabila patogen berhasil masuk, tubuh akan mendeteksi jika patogen tersebut berasal dari luar tubuh, sehingga tubuh akan memberikan reaksi secara terkoordinir dari sel dan senyawa yang ada pada tubuh, dan akan memberi reaksi melawan patogen (Amalia \& Hiola, 2020).

Masa pandemi Covid 19 menuntut kita untuk meningkatkan imunitas tubuh. Banyak upaya yang dapat dilakukan, salah satunya yaitu menjaga asupan gizi. Gizi adalah aspek yang mempunyai hubungan dengan fungsi dasar zat gizi yaitu menghasilkan energi, mengatur proses 
metabolisme, pertumbuhan, dan pemeliharaan jaringan dalam tubuh (Mardalena \& Suryani, 2016). Gizi Seimbang adalah makanan yang dikonsumsi oleh seseorang sehari-hari yang beraneka ragam dan memenuhi 5 kelompok zat gizi dalam jumlah yang cukup, tidak berlebihan dan tidak kekurangan (Kemenkes RI, 2020).

Setelah dilakukan penyuluhan tentang upaya meningkatkan imunitas tubuh di masa pandemi Covid 19, banyak ibu-ibu majelis taklim Masjid Ar Ridho yang sudah paham bagaimana upaya dalam meningkatkan imunitas tubuh di masa pandemi Covid 19. Hal ini dibuktikan dengan beberapa ibu-ibu majelis taklim Masjid Ar Ridho sudah mampu merespon pertanyaan pemateri terkait upaya dalam meningkatkan imunitas tubuh di masa pandemi Covid 19. Beberapa ibu-ibu majels taklim Ar Ridho menjawab salah satu upaya meningkatkan imunitas tubuh di masa pandemi Covid 19 adalah dengan menjaga asupan gizi yang seimbang. Hal ini sejalan dengan penelitian yang dilakukan Ramadhani \& Khofifah (2021) dimana didapatkan hasil bahwa terdapat peningkatan pengetahuan remaja terhadap gizi seimbang sebelum dan sesudah dilakukannya penyuluhan dengan nilai $\mathrm{p}$ diperoleh sebesar 0,000.

Menjaga pola makan yang baik dan sehat sangat penting selama pandemi Covid 19. Walaupun tidak ada makanan atau suplemen makanan yang dapat mencegah penularan virus Covid 19, mengubah pola makan dengan mengkonsumsi makan bergizi seimbang yang sehat dan sangat penting dalam meningkatkan sistem kekebalan tubuh yang baik. Konsumsi makanan dengan gizi seimbang dan aman dapat meningkatkan sistem kekebalan tubuh dan menurunkan resiko penyakit kronis dan penyakit infeksi. Cobalah untuk membuat variasi dalam menu makanan saat dirumah agar keluarga tidak menjadi bosan dengan menu makanan yang sama (Kemenkes RI, 2020).

WHO telah merekomendasikan menu gizi seimbang ditengah pandemi COVID-19. Artinya, disetiap menu makanan harus mencakup nutrisi lengkap, baik itu makronutrien seperti karbohidrat, protein, lemak, serta mikronutrien dari vitamin dan mineral. Namun, untuk membuat fondasi daya tahan tubuh yang kuat (building block), kita harus fokus pada asupan protein (Kemenkes RI, 2020). Dampak dari pandemi pada kehidupan seseorang dan masyarakat pada bidang pangan juga akan terjadi. Penyelesaian masalah Covid 19 ini pada dampak sosial tidak bisa hanya diserahkan pada pemerintah tetapi setiap keluarga harus berusaha untuk mengatasi masalah terutama pangan. Karena jika pangan tersedia tidak akan terjadi kelaparan dan masalah sosial lanjutan (Kemenkes RI, 2020).

Masyarakat harus membiasakan mengonsumsi aneka ragam makanan pokok. Batasi konsumsi makanan yang manis, asin, dan berlemak. Lakukan kebiasaan mengkonsumsi lauk pauk yang mengandung protein tinggi. Perbanyak makan buah dan sayuran karena sayuran dan buah-buahan kaya akan vitamin dan zat gizi yang baik untuk tubuh.

Kementerian Kesehatan Republik Indonesia memperhatikan asupan makanan yang bisa dan dapat meningkatkan sistem kekebalan tubuh yang harus terpenuhi selama pandemi Covid19 (Ferdiaz, 2020). Pengetahuan gizi merupakan pengetahuan tentang makanan dan zat gizi. Sikap dan perilaku ibu dalam memilih makanan yang akan dikonsumsi dipengaruhi oleh berbagai faktor, diantaranya adalah tingkat pengetahuan seseorang tentang gizi sehingga dapat mempengaruhi status gizi seseorang tersebut. Pengetahuan gizi ibu yang kurang dapat menjadi salah satu penentu status gizi karena menentukan sikap atau perilaku ibu dalam memilih makanan yang akan dikonsumsi serta pola makan terkait jumlah, jenis dan frekuensi yang akan mempengaruhi asupan makan pada keluarga tersebut (Wahyuni, 2009).

Selain menjaga asupan gizi, ibu-ibu majelis taklim Masjid Ar Ridho juga menjawab untuk meningkatkan imunitas tubuh di masa pandemi Covid 19 salah satunya yaitu perbanyak aktivitas fisik yang cukup seperti berolah raga. Aktivitas fisik adalah hal yang tidak dapat dipisahkan dari tubuh manusia. Secara bahasa, aktivitas fisik adalah gerakan tubuh yang dihasilkan otot dan rangka dan membutuhkan energi untuk melakukannya. Menurut salah satu 
ahli, aktivitas fisik adalah serangkaian kemampuan yang dimiliki individu untuk melakukan aktivitas sehari-hari (Williams, 2017).

Berdasarkan hasil dari literature review yang dilakukan Apituley, dkk (2021), didapatkan bahwa olahraga mampu meningkatkan sistem imunitas, kesehatan metabolik, kesehatan mental, kekuatan otot dan fungsi kardiovaskular. Manfaat olahraga diperoleh jika melakukan olahraga intensitas sedang dengan teratur. Secara umum olahraga yang disarankan yaitu melakukan olahraga aerobik dan anaerobik di rumah. Sebagai simpulan, olahraga memberi pengaruh yang baik terhadap Covid 19.

Dalam peningkatan imunitas tubuh diperlukan latihan fisik dengan intensitas sedang. Latihan fisik dengan intensitas sedang menstimulasi imunitas seluler, sementara latihan yang berkepanjangan atau intensitas berat tanpa istirahat yang tepat, dapat memicu penurunan imunitas seluler, meningkatkan kecenderungan penyakit menular (da Silveira et al, 2020). Melakukan olahraga intensitas sedang, dengan durasi kurang dari 60 menit, terjadi peningkatan immunosurveillance dari sub-tipe sel imun yang mempunyai efek terapeutik dan preventif. Respons dari latihan fisik sedang ialah dapat meningkatkan aktivitas anti-patogen dari makrofag yang timbul bersamaan dengan peningkatan resirkulasi immunoglobulin, sitokin anti-inflamasi, neutrophil, sel natural-killer (NK), sel T sitotoksik, dan sel B, yang semuanya mempunyai peran penting dalam imunitas tubuh (Tiksnadi dkk, 2020).

Diharapkan juga dengan adanya penyuluhan ini, ibu-ibu majelis taklim Masjid Ar Ridho mampu melakukan berbagai upaya meningkatkan imunitas tubuh di masa pandemi Covid 19 seperti menjaga asupan gizi yang seimbang, rutin melakukan aktifitas fisik sedang seperti berolah raga, istirahat yang cukup dan menghindari stress. Dan diharapakan ibu-ibu majelis taklim Masjid Ar Ridho mampu mengajak dan mempengaruhi keluarga di rumah untuk hidup lebih sehat dengan menjaga pola makan yang sehat agar terhindar dari penyakit Covid 19.

\section{SIMPULAN}

Kegiatan penyuluhan dengan tema "Upaya Meningkatkan Imunitas Tubuh di Masa Pandemi Covid-19" merupakan kegiatan pemberian edukasi kepada masyarakat khususnya ibu-ibu majelis taklim Masjid Ar-Ridho mengenai pentingnya meningkatkan imunitas tubuh kita dalam mencegah tertular virus Covid-19 yang telah menjadi bencana nasional di negara Indonesia. Kegiatan Pengabdian Kepada Masyarakat (PKM) pada ibu-ibu majelis taklim Masjid Ar-Ridho disambut baik oleh peserta penyuluhan. Dari segi program kegiatan ini dilaksanakan dengan baik sesuai yang direncanakan, kegiatan ini bertujuan positif untuk memberi pemahaman dari segi pengetahuan dan keterampilan kepada ibu-ibu majelis taklim Masjid Ar-Ridho akan pentingnya meningkatkan imunitas tubuh di masa pandemi Covid-19.

Berdasarkan hasil yang diperoleh dapat disimpulkan bahwa terjadi peningkatan pengetahuan dan keterampilan peserta penyuluhan yaitu ibu-ibu majelis taklim Masjid ArRidho mengenai pentingnya meningkatkan imunitas tubuh di masa pandemi Covid-19 sebagai upaya pencegahan penularan Covid-19.

Saran bagi ibu-ibu majelis taklim Masjid Ar-Ridho setelah kegiatan Pengabdian Kepada Masyarakat (PKM) ini diharapkan perlu mengadakan sosialisasi lanjutan kepada masyarakat ataupun khususnya dengan keluarga masing-masing agar semua masyarakat di sekitar Masjid Ar-Ridho paham mengenai pentingnya meningkatkan imunitas tubuh di masa pandemi Covid-19 dan dapat menerapkannya sebagai bentuk pencegahan penularan Covid-19. 


\section{Ucapan Terima Kasih}

Kami mengucapkan terimakasih banyak ke berbagai pihak dalam pelaksanaan kegiatan ini, yaitu kepada Ketua BKM Masjid Ar Ridho dan Ketua LPPM Institut Kesehatan Helvetia yang memberikan dukungan penuh terhadap pelaksanaan kegiatan pengabdian masyarakat oleh Dosen Institut Kesehatan Helvetia terhadap masyarakat yang membutuhkan.

\section{Daftar Pustaka}

Amalia, L., \& Hiola, F. (2020). Analisis Gejala Klinis dan Peningkatan Kekebalan Tubuh untuk Mencegah Penyakit Covid-19. Jambura Journal of Health Sciences and Research, 2(2), 71-76. https://doi.org/10.35971/jjhsr.v2i2.6134

Apituley, T. L. D., Pangemanan, D. H. C., \& Sapulete, I. M. (2021). Pengaruh Olahraga Terhadap Coronavirus Disease 2019. Jurnal Biomedik, 13(1), 111-117. https://ejournal.unsrat.ac.id/index.php/biomedik/index

da Silveira, M. P., da Silva Fagundes, K. K., Bizuti, M. R., Starck, É., Rossi, R. C., \& de Resende e Silva, D. T. (2020). Physical exercise as a tool to help the immune system against COVID-19: an integrative review of the current literature. In Clinical and Experimental Medicine. https://doi.org/10.1007/s10238-020-00650-3

Ferdiaz, N. Y. (2020). Kekurangan Gizi Penyebab Kematian Anak Akibat Virus Corona, Kemenkes Bagikan Cara Praktis Mencukupi Kebutuhan Gizi Anak di Tengah Pandemi Covid-19. Jurnal Kesehatan.

Kementrian Kesehatan RI. (2020). Panduan Gizi Seimbang Pada Masa Pandemi COVID-19. Artikel Kesehatan.

Kementrian Kesehatan RI. (2020). Pedoman Pencegahan dan Pengendalian Coronavirus Disease (Covid-19). Direktorat Jenderal Pencegahan dan Pengendalian Penyakit

Liu J, Liao X, Qian S et al (2020). Community transmission of severe acute respiratory syndrome coronavirus 2, Shenzhen, China. Emerg Infect Dis 2020 doi.org/10.3201/eid2606.200239

Moderbacher, C. R., Ramirez, S. I., Dan, J. M., Smith, D. M., Sette, A., \& Crotty, S. (2020). Antigen-Specific Adaptive Immunity to SARS-CoV-2 in Acute COVID-19 and Associations with Age and Disease Severity. Cell, 183(4), 996-1012.e19. https://doi.org/10.1016/j.cell.2020.09.038

Mardalena, I., \& Suyani, E. (2016). Ilmu Gizi. Kementerian Kesehatan Republik Indonesia, 182.

Mutmainah, A.N., \& Jamilatun, M. (2021). Pemberdayaan Masyarakat di Kampung Kroyo, Karangmalang Sragen dalam Penerapan PHBS sebagai Upaya Pencegahan dan Penanggulangan Covid-19. Jurnal Abdi MOESTOPO,4(01), 6-11.

Ramadhani, K., Khofifah, H. (2021). Edukasi Gizi Seimbang Sebagai Upaya Meningkatkan Pengetahuan pada Remaja di Desa Bedingin Wetan pada Masa Pandemi Covid-19. Jurnal Kesehatan Global, 4(2), 66-74. http://ejournal.helvetia.ac.id/index.php/jkg

Tiksnadi, B. B., Sylviana, N., Cahyadi, A. I., \& Undarsa, A. C. (2020). Olahraga Rutin untuk Meningkatkan Imunitas Pasien Hipertensi Selama Masa Pandemi COVID-19. Indonesian Journal of Cardiology, 41(2), 112-119. https://doi.org/10.30701/ijc.1016

Wahyuni, I. (2009). Pengetahuan Ibu tentang Gizi dengan Status Gizi Anak Balita di Desa Ngemplak Kecamatan Karangpandan Kabupaten Karanganyar. Skripsi. Surakarta: Universitas Sebelas Maret

Williams, M. H. (2017). Nutrition For Health, Fitness And Sport: Eleventh Edition. In McGraw-Hill Education (11 ed.). McGraw-Hill Education. 
World Health Organization. (2020). Coronavirus disease (COVID-19): weekly epidemiological update. 